\title{
PENGEMBANGAN MEDIA PEMBELAJARAN TEKNIK PASSING BAWAH MENGGUNAKAN MEDIA GAMBAR DALAM PADA PERMAINAN BOLA VOLI DI SMP SANTA VERONIKA
}

\section{DEVELOPMENT OF UNDERHAND PASS TECHNIQUE LEARNING MEDIA USING THE MEDIA IMAGE IN VOLLEYBALL GAMES IN JHS SANTA VERONIKA}

\author{
Aref Vai1 ${ }^{1}$ Jul Ferdi Jawak², Ni Putu Nita Wijayanti³ ${ }^{3}$ Aulia Gusdernawati* \\ 1,2 Pendidikan Jasmani Kesehatan dan Rekresi Universitas Riau, Indonesia \\ 3,Pendidikan Kepelatihan Olahraga, Universitas Riau, Indonesia \\ ${ }^{4}$ Ilmu Keolahragaan Program Pascasarjana Universitas Negeri Yogyakarta, Indonesia
}

*Corresponding Author: Aulia Gusdernawati, gusdernawati5@gmail.com

Received: 2021-05-04; Revised: 2021-06-15; Accepted: 2021-07-11

\begin{abstract}
Abstrak
Penelitian ini bertujuan untuk mengembangkan media pembelajaran khusus pada materi ajar permainan bola voli yaitu teknik passing dengan media gambar yang di khususkan untuk SMP Santa Veronika. Media pembelajaran sangat dibutuhkan dalam menjembatani guru menyampaikan pesan pada siswa, untuk mengurangi kegagalan dalam komunikasi selama proses pembelajaran berlangsung. Penelitian pengembangan ini menggunakan metode serta langkah-langkah dalam penelitian ini menggunakan model ADDIE yang meliputi 5 tahap yaitu Analysis, Design, Development, Implementation, dan Evaluation. Subjek pada penelitian ialah satu orang ahli materi, satu orang ahli media, dan 14 orang siswa pengguna media pembelajaran, penelitian dilaksanakan di Sekolah SMP Santa Veronika. Hasil penelitian pengembangan media gambar passing bawah pada permainan bola voli yang diuji pada kelompok kecil dinyatakan sangat layak dan baik digunakan sebagai media pembelajaran serta dapat dijangkau oleh siswa. Dengan catatan masih perlu melakukan pengujian secara kelompok besar dalam penggunaaan media ini agar diketahui apakah media pembelajaran ini dapat digunakan oleh pengguna secara luas.
\end{abstract}

Kata Kunci: media gambar, pembelajaran, passing bawah, bola voli

\begin{abstract}
This study aims to develop a special learning media for volleyball teaching material, namely the passing technique using image media which specially for JHS Santa Veronika. Learning media is needed in bridging teachers to convey messages to students, to reduce failures in communication during the learning process. This development research uses the method and the steps in this study using the ADDIE model which includes 5 stages, namely Analysis, Design, Development, Implementation, and Evaluation. The subjects in the study were one material expert, one media expert, and 14 students using learning media. The research was carried out at Santa Veronika Junior High School. The results of the research on the development of the under-passing image media in volleyball games were tested on a small scale that this media is very feasible and good to use as a learning medium and can be reached by students With a note that it is still necessary to do large group testing in the use of this media so that it is known whether this learning media can be used by users widely.
\end{abstract}

Keywords: image media, learning, passing, volleyball

How To Cite: Vai, A., Jawak, J.F., Wijayanti, N.P.N., Gusdernawati, A. (2021). Pengembangan media pembelajaran teknik passing bawah menggunakan media gambar dalam pada permainan bola voli di smp santa veronika. Journal of Sport Education (JOPE), 3 (2), 127-136. doi:http://dx.doi.org/10.31258/jope.3.2.127-136

Journal of Sport Education (JOPE) is an open access article under the CC-BY-SA 4.0 


\section{PENDAHULUAN}

Metode pembelajaran yang digunakan pada pendidikan jasmani berfokus pada pengetahuan, sikap, dan perilaku bagian dari pendidikan jasmani secara umum (Darst et al., 2014). Selain itu pendidikan jasmani didesain metode pembelajarannya untuk mengembangkan keterampilan motorik, meningkatkan pengetahuan, meningkatkan kebugaran jasmani, perilaku hidup sehat, kecerdasan emosional, serta sikap sportif melalui aktivitas fisik (Nasution, 2018; Kesumawati, Rahayu, and Rahayu 2018; Hanief 2017). Pendidikan jasmani memiliki beberapa aspek yang sudah ada pada siswa dapat di kembangkan dengan maksimal dalam pendidikan secara menyeluruh. Untuk membantu siswa melakukan aktivitas sehari-hari dan memahami mengapa manusia bergerak dan dapat melakukan gerakan secara aman, efektif, dan efisien maka perlu menyajikan pengalaman belajar. Pengalaman pembelajaran merupakan kegiatan belajar pada siswa, untuk mempersepsikan pengalaman belajar dan tujuan pembelajaran (Roberts et al., 2018). Mendapatkan pengalaman pembelajaran yang menarik bagi siswa mengharuskan guru mampu merancang pembelajaran yang baik. Oleh sebab itu pembelajaran yang menarik sangat diharapkan oleh seluruh tenaga pengajar dan siswa dalam proses pembelajaran, untuk mendapatkan pembelajaran yang menarik banyak faktor dalam penentunya. Kemudian dalam mengimplementasikan metode, strategi, dan model pembelajaran, guru juga harus mampu menyiapkan media pembelajaran yang cukup inovatif dan menarik dalam proses pembelajaran. Dalam memilih media pembelajaran yang akan digunakan perlu dengan inti dari pembelajaran (Santoso, 2019). Semakin menarik media pembelajran yang ditampilkan seorang guru, maka semakin menarik rasa ingin tahu, motivasi, minat dan kreativitas siswa untuk memaksimalkan capaian pembelajaran (Dewi, Murtinugraha, dan Arthur 2018).

Media pembelajaran sangat dibutuhkan untuk perantara guru dalam menyampaikan pesan kepada siswa, untuk mengurangi kegagalan dalam komunikasi selama proses pembelajaran berlangsung (Mustaqim, 2017). Hal ini sejalan dengan Haryoko (2012) menyatakan media pembelajaran sebagai teknik, alat, dan metode yang digunakan untuk mempermudah komunikasi anatara guru dan siswa supaya mencapai proses pembelajaran yang efektif. Lebih lanjut Cecep dan Bambang (2011) bahwa dalam media pembelajaran dibagi menjadi empat kelompok diantaranya a) media teknologi audio visual, b) berbasis komputer, 3) teknologi cetak, 4) dan teknologi computer dan cetak. Dari empat kelompok jenis media tersebut dalam penggunaannya supaya lebih maksimal dengan cara menggabungkan teknologi cetak dan komputer, karena bentuk dari beberapa media tersebut yang di dalamnya dapat dikendalikan oleh komputer. Dewasa ini pengembangan media pembelajaran telah banyak diteliti, diantaranya peneletian Irfiandita, (2014) bahwa media pembelajaran yang menarik dan inovatif sangat mendukung dari berhasilnya dalam proses pembelajaran dan hasil tes dalam penelitian tersebut disimpulkan bahwa hasil pembelajaran passing bawah bola voli dalam kelompok eksperimental diberi perlakuan menggunakan media pembelajaran lebih baik daripada hasil belajar passing bawah bola voli dalam kelompok kontrol yang tidak diberi perlakuan menggunakan media pembelajaran. Selain itu juga ada beberapa penelitian yang mengembangkan beberapa media pembelajaran yang dilakukan oleh Vai, Juita, and Sulaastio (2019) tentang Pengembangan Media Pembelajaran Pencak Silat Berbasis Multimedia Tingkat SMA/Ma. Vai et al. (2021) mengembangkan media pembelajaran pencak silat berbasis Lectora Inspire. Penelitian ini menghasilkan sebuah produk lectora inspire yaitu media pembelajaran tentang perwasitan pencak silat berbasis audio visual yang diaplikasikan. Selanjutnya penelitian Amir (2016) bahwasanya pembelajaran matematika dapat meningkatkan hasil belajar matematika. Lebih lanjut penelitian Fitria (2017) dengan judul pengembangan media gambar berbasis lokal yang menunjukkan bahwa meningkatnya keefektifan pembelajaran melalui media gambar berbasis lokal. 
Salah satu materi dalam pembelajaran pendidikan jasmani ialah permainan bola voli yang terdapat dalam kurikulum sekolah menengah pertama yang dipelajari dalam merumuskan berbagai aspek terkait dan rencana pembelajaran (Kesumawati et al., 2019). Lebih lanjut permainan bola voli telah populer dimainkan di kalangan masyarakat dan pada ranah pendidikan, bola voli telah dikenalkan mulai dari jenjang SD hingga jenjang SMA (Fani \& Sukoco, 2019). Materi passing bawah bola voli seharusnya disajikan dengan teori dan praktik, sehingga pada kegiatan pembelajaran siswa mampu menguasai teknik passing bawah sesuai dengan materi yang diajarkan pada tiap semester dan jenjangnya. Pada kurikulum K13 pendekatan pembelajaran bersifat saintific artinya keaktifan siswa dalam proses pembelajaran sangat diutamakan. Jadi peran media yang digunakan guru sangat besar untuk merangsang siswa aktif dalam pembelajaran. Hal itu disebabkan oleh metode yang digunakan saat pembelajaran yang lebih mengarah dalam metode ceramah dan komando, penggunaan metode ini cenderung digunakan karena keadaan dan kurangnya media pembelajaran yang tersedia, serta pembelajaran yang didasarkan pada materi, bukan merupakan kombinasi yang baik dari segi bahan ajar, teori, dan bahan ajar. Di saat proses belajar dalam kelas yang mengajarkan gerakan-gerakan detail, dilakukan dengan melihat dan berdiskusi selanjutnya siswa melakukan gerakan tersebut melalui imajinasinya.

Menurut Kuswoyo (2013) dalam sebuah permainan bola voli pemain harus mampu menguasai teknik dasar bola voli, khususnya teknik dasar yang sangat perlu dikuasai ialah teknik pasing bawah, karena passing bawah bertujuan mengoper bola yang dimainkan pada rekan satu timnya. Jika penguasaan passing bawah dapat dilakukan dengan baik maka akan menjadi lebih mudah untuk membendung serangan dari lawan, menerima servis, serta mampu memberikan operan bola yang baik pada tim untuk melakukan pukulan serangan kepada lawan (Sarjianto, 2010). Salah satu teknik dasar pada permainan bola voli yang mudah untuk dikuasai dari teknik yang lain ialah passing bawah dan passing atas. Namun juga tidak menutup kemungkinan siswa akan melakukan kesalahan dalam mempraktikkan teknik passing bawah, sehingga kualitas passing bawah yang telah dipraktikkan siswa tidak sesuai dengan yang diharapkan.

Dengan beberapa kajian dan teori yang diuraikan, salah satu penyelesaiannya adalah dengan menggunakan media gambar sebagai produk media pembelajaran yang memperjelas materi yang akan disampaikan. Tentunya, jika hanya menggunakan media buku tidak akan mendapatkannya. Penggunaan media pembelajaran menggunakan gambar ini akan memberikan daya tarik dan meningkatkan pemahaman untuk mempelajari berbagai materi khususnya dalam pembelajaran bola voli pada teknik dasar passing bawah. Adapun tujuan dari penelitian ini membuat suatu produk pembelajaran yang berbasis media gambar yang telah di validasi, media gambar passing bawah bola voli menawarkan kemudahan, penyempurnaan pembelajaran, dan sebagai sumber alternatif yang digunakan guru dan siswa khususnya di SMP Santa Veronika.

\section{METODE}

Pendekatan yang dilakukan dalam metode penelitian ini adalah dengan pendekatan metode penelitian pengembangan atau juga dikenal dengan Research \& Development. Tempat penelitian dilakukan di Sekolah SMP Santa Veronika Sugiyono (2019) mengemukakan bahwa penelitian dan pengembangan sebagai metode penelitian yang digunakan untuk membuats suatu produk tertentu dan menguji validitas keefektifan produk tersebut. Adapun langkahlangkah dalam penelitian ini menggunakan model ADDIE diantaranya meliputi 5 fase yaitu Analysis, Design, Development, Implementation, dan Evaluation (Branch, 2020). Subjek penelitian ini adalah 1 validator materi oleh akademisi Jurusan Pendidikan Olahraga di Universitas Riau, 1 validator media oleh pendidik SMK Negeri 5 Pekanbaru, 14 orang siswa SMP Santa Veronika sebagai pengguna media pembelajaran. 
Penelitian ini dengan uji coba dengan kelompok kecil untuk menganalisis reliabilitas instrument dengan pertimbangan efisiensi biaya dan waktu penelitian. Instrument yang digunakan ialah instrument berupa angket dengan skala likert berisi pernyataan supaya sistematis untuk mendapatkan data penelitian dengan teknik analisis deskriptif kuantitatif. Analisis data menggunakan langkah awal observasi, kemudian uji statistik data yang sudah diperoleh dari penilaian ahli materi dan ahli media yang berisikan aspek pembelajaran dan aspek materi/isi. Serta hasil uji coba kelompok kecil pada siswa SMP Santa Veronika yang berisi penilaian aspek tampilan, materi/isi, dan pembelajaran untuk menentukan kriteria dari hasil uji coba produk. Adapun gambaran alur dari penelitian ini disajikan pada gambar 1 sebagai berikut:

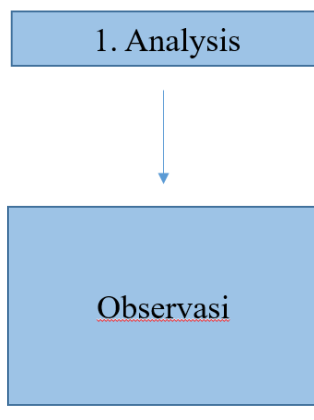

\section{HASIL}

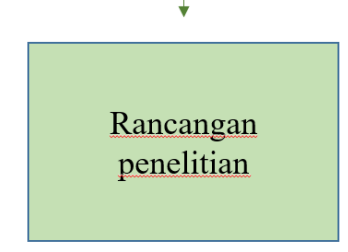

2. Design
4. Implementation

3. Development

Gambar 1. Alur Penelitian

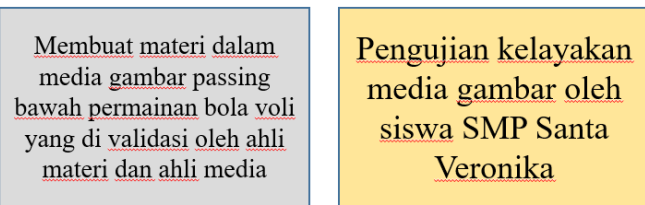
Hasil peneilaian dari ahli materi, ahli media, dan siswa SMP Santa Veronika menjadi evaluasi apabilaterdapat
perbaikan akan dilakukan

5. Evaluation

Produk dari penelitian pengembangan ini berupa gambar passing bawah bola voli untuk siswa di Sekolah Menengah Pertama, Pada siswa SMP Santa Veronika Pekanbaru. Gambar passing bawah bola voli dikemas ke dalam sebuah gambar yang telah disajikan sesuai mata pelajaran bola voli tersebut berisi langkah-langkah melakukan passing bawah. Dalam mempraktikkan gambar passing bawah, siswa dapat berinteraksi langsung dengan media pembelajaran ini untuk melihat dengan teliti satu persatu gambar yang telah disajikan oleh materi. Interaksi ini berupa gambar yang bisa dilihat dan ditirukan pergerakan sesuai langkah pada tutorial yang ada pada gambar dan sesuai pada media pembelajaran. Dalam penciptaan gambar passing bawah untuk permainan bola voli ini dikerjakan dalam software adobe flash cs6. Penampilan produk yang disajikan pada gambar 2 merupakan produk awal sebelum direvisi dan produk yang sudah melalui tahap revisi oleh ahli materi dan media disajikan pula pada gambar 3 sebagai berikut:

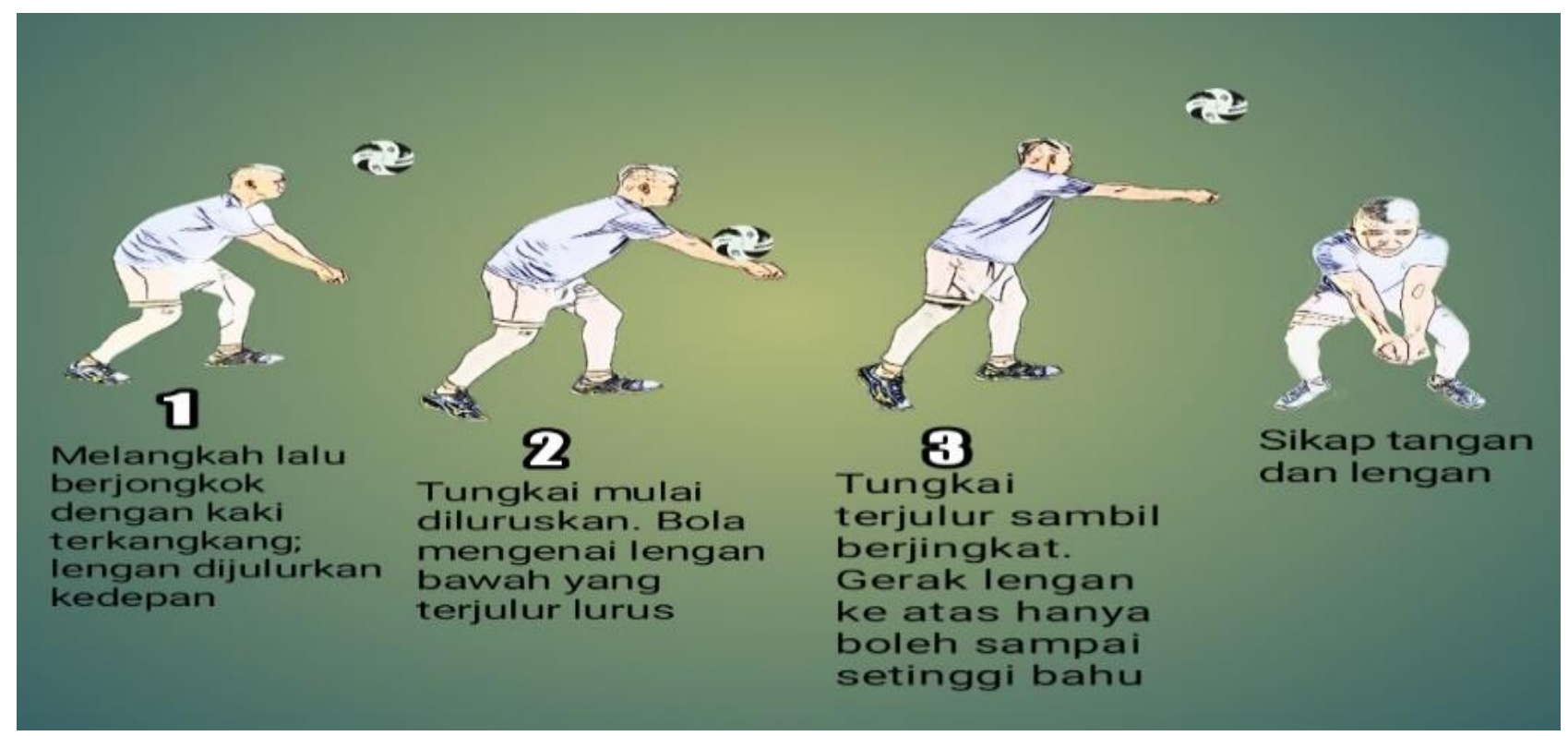

Gambar 2. Daftar produk sebelum revisi media teknik passing bawah bola voli 
Dari media gambar passing bawah yang telah di sajikan pada gambar 2 merupakan produk awal sebelum di revisi dimana gambar yang disajikan dalam bentuk karikatur, tidak ada keterangan pada gambar, dan font tulisan kurang rapi. Pada gambar 3 setelah dilakukan revisi oleh ahli materi dan media yang merupakan penyempurnaan dari produk sebelumnya, gambar yang telah di revisi lebih jelas, terdapat keterangan pada gambar, dan font yang digunakan lebih rapi dari sebelumnya.

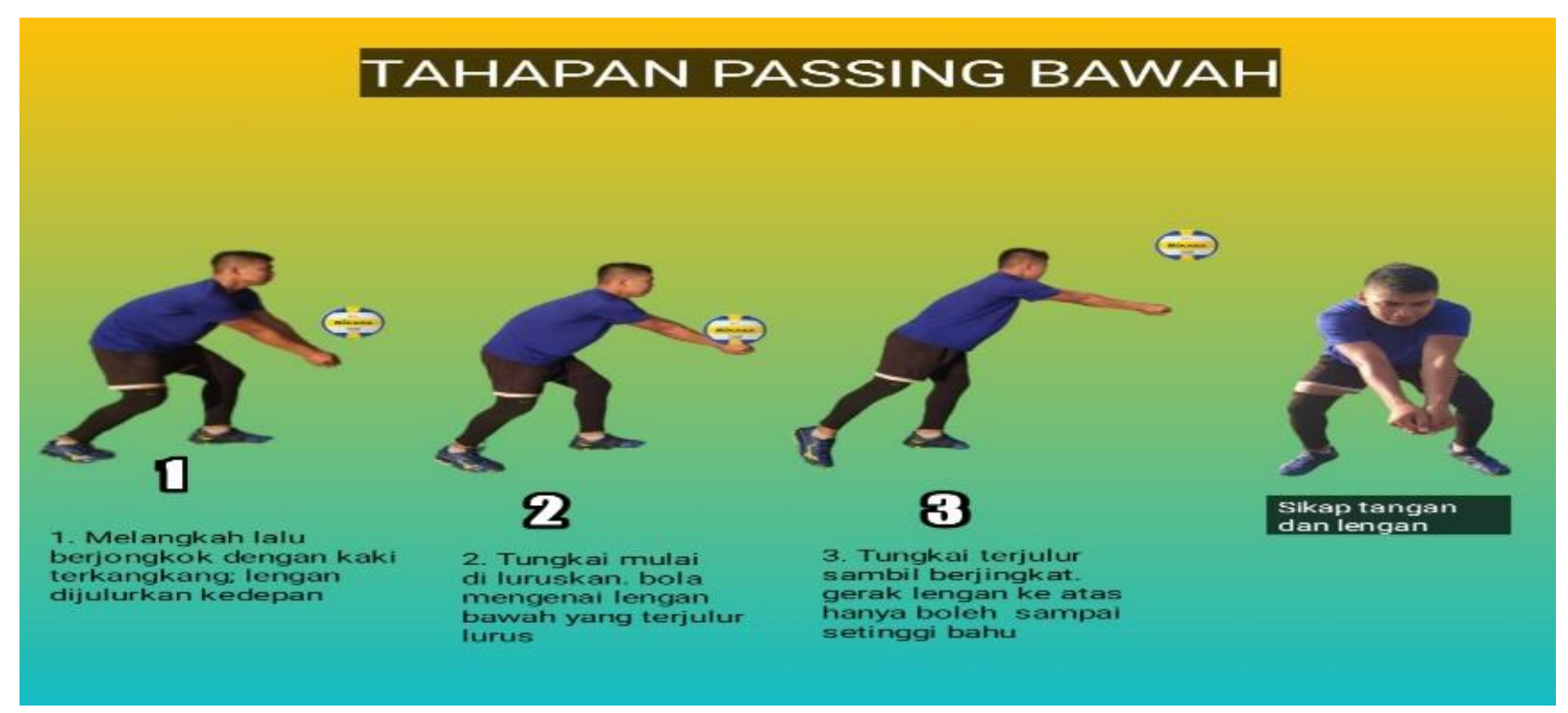

Gambar 3. Daftar produk setelah revisi media teknik passing bawah bola voli

Berdasarkan hasil penilaian media pembelajaran gambar passing bawah dalam permainan bola voli yang disajikan pada tabel 1 terdapat penilaian aspek pembelajaran didapatkan nilai sebesar 3.9 masuk pada kategori "baik", kemudian dilihat dari segi kualitas gambar materi diperoleh hasil sebesar 3.7 berada dalam kategori "baik", dan hasil penilaian pada aspek ukuran gambar materi hasil yang didapat sebesar 3.8 masuk dalam kategori "baik". Dari hasil penelitian yang didapat diartikan bahwa produk media gambar telah baik untuk digunakan menjadi materi media pembelajaran, namun terdapat catatan yang berupa komentar, kritik, dan saran dari ahli materi untuk diperbaiki yaitu dalam praktek lapangan nantinya untuk warna gambar, tulisan pada gambar jangan sampai berubah, tetap seperti yang sudah dibuat sekarang, supaya siswa dengan cepat mudah menangkap apa isi materi pembelajaran yang disampaikan. Dan menurut ahli materi bahwa media gambar passing bawah bola voli ini dinyatakan layak untuk digunakan yang telah di uji coba dalam kelompok kecil tanpa revisi. Untuk lebih rinci hasil penilaian dari ahli materi yang telah disajikan pada tabel 1 dapat dilihat sebagai berikut:

Tabel 1. Hasil Penilaian Ahli Materi

\begin{tabular}{ccc}
\hline Aspek yang dinilai & Skor Rata-Rata & Kriteria \\
\hline Aspek Pembelajaran & 3.9 & Baik \\
Aspek Materi/Isi & 3.7 & Baik \\
Rata-rata & $\mathbf{3 . 8}$ & Baik \\
\hline
\end{tabular}

Produk dan angket media pembelajaran gambar passing bawah dalam permainan bola voli untuk tahap kedua pada siswa SMP Santa Veronika Pekanbaru yang di konsultasikan oleh ahli media. Berdasarkan tabel di atas diketahui hasil pembelajaran teknik passing bawah bola 
voli pada siswa SMP Santa Veronika Pekanbaru dengan menggunakan media gambar teknik passing bawah, didapatkan hasil pada aspek pembelarajan dengan nilai sebesar 3.58 dengan kategori "baik", kemudian pada aspek materi dengn nilai 3.60 poin masuk pada kriteria "baik", dan nilai rata-arata pada aspek media sebesar 3.59 masuk dalam kategori "baik". Berdasarkan hasil penelitian menunjukkan bahwa produk media gambar sangat baik dan juga layak untuk media pembelajaran khususnya pada passing bawah bola voli. Media pembelajaran yang dikembangkan ini juga layak untuk digunakan uji coba tanpa adanya revisi. Dengan terpenuhinya fasilitas belajar mandiri ini diharapkan dapat meningkatkan minat belajar siswa. Untuk lebih jelasnya Tabel 2 menunjukkan hasil evaluasi oleh ahli media sebagai berikut.

Tabel 2. Hasil Penilaian Ahli Media

\begin{tabular}{ccc}
\hline Aspek yang dinilai & Skor Rata-Rata & Kriteria \\
\hline Aspek Pembelajaran & 3,58 & Baik \\
\hline Aspek Materi/Isi & 3,60 & Baik \\
\hline Rata-rata & $\mathbf{3 , 5 9}$ & Baik
\end{tabular}

Setelah dilakukan pengujian oleh ahli media dan materi, selanjutnya media pembelajaran gambar passing bawah diuji cobakan kepada siswa SMP Santa Veronika Pekanbaru untuk digunakan untuk pembelajaran. Selanjutnya melakukan uji coba produk media pembelajaran gambar passing bawah dalam kelompok kecil pada siswa SMP Santa Veronika Pekanbaru yang dilakukan sekali. Bersumber pada hasil uji coba sekala kecil oleh siswa, maka diperoleh jawaban siswa tentang media pembelajaran gambar passing bawah dalam permainan bola voli pada siswa SMP Santa Veronika Pekanbaru. Tanggapan siswa dalam penggunaan media gambar pada pembelajaran passing bawah permainan bola voli dalam aspek tampialn dengan nilai 3.87 kategori (baik). Kemudian pada indikator materi/isi dengan niali 3.47 kategori baik serta pada indikator pembelajaran 3.67 dengan kriteria baik hasil uji coba kelompok kecil kepada siswa diperoleh pada tabel 3 sebagai berikut:

Tabel 3. Uji Coba Kelompok Kecil

\begin{tabular}{ccc}
\hline Aspek yang dinilai & Skor Rata-Rata & Kriteria \\
\hline Tampilan & 3.87 & Baik \\
\hline Materi/Isi & 3.47 & Baik \\
\hline Pembelajaran & 3.67 & Baik \\
\hline Rata-Rata & $\mathbf{4 . 3 5}$ & Baik \\
\hline
\end{tabular}

\section{PEMBAHASAN}

Pengembangan media pembelajaran gambar passing bawah dalam pembelajaran bola voli menurut validasi ahli dan tanggapan siswa maka pengembangan media ini layak untuk digunakan untuk proses pembelajaran. Begitu amat pentingnya media pembelajaran yang harus dimiliki guru dalam proses pembelajaran, karena media pembelajaran sangat berperan aktif dalam merangsang keaktifan siswa dalam pembelajaran. Sejalan dengan pernyataan Mustaqim (2017) media pembelajaran tidak bisa berpisah dalam sebuah proses belajar mengajar, hal ini dikarenakan keberhasilan materi yang akan disampaikan guru dapat dipengaruhi dengan penggunaan media pembelajaran. Mendesain media dalam sebuah permainan dapat memberikan kesempatan kepada siswa untuk mengembangkan pengetahuan serta keterampilan terstruktur mengarah pada imajinasi dan penemuan bagi siswa (Leech \& Marston, 2016).

Media pembelajran yang menarik dapat merespon siswa untuk berimajinasi dalam 
memahami materi yang disajikan guru melalui media yang mereka gunakan, oleh karenanya sangat perlu kejelian dalam menentukan media yang akan digunakan. Seperti kita ketahui, dalam era revolusi industri 4.0 dan society 5.0 guru sudah harus aktif berperan serta dalam menggunakan media yang berbasis digital. Maka dari itu sekolah harus mempersiapkan sarana untuk mendukung kegiatan tersebut terutama skolah sudah menyiapakan perangkat internet. Ada beberapa artikel yang sudah mengembangkan media pembelajaran diantaranya penelitian Irfiandita (2014) berjudul Penerapan Media Poster Dan Media Audiovisual Terhadap Hasil Belajar Pada Materi Passing Bawah Bola Voli yang menghasilkan adanya pengaruh hasil belajar dan domain keterampilan passing bawah dengan menggunakan media poster dan audiovisual. Vai et al. (2019) The Media Development of Pencak Silat Learning Multimedia Based at SMA/MA. Penelitian tersebut menghasilkan sebuah model pembelajaran berbasis IT. Software yang digunakan dalam proses pembuatan model pembelajaran tersebut adalah adobe flash cs. Selain itu, Penelitian model pembelajaran pencak silat berbasis IT lainnya dengan judul Pengembangan Media Pembelajaran Pencak Silat Berbasis Macromedia Flash 8 Untuk Sekolah Menengah Pertama juga pernah dilakukan oleh Valentino and Ihsan (2018). Penelitian tersebut menghasilkan sebuah produk berupa DVD media pembelajaran Multimedia Interaktif menggunakan aplikasi macromedia flash 8 pada mata pelajaran PJOK materi pencak silat kelas VIII. Selanjutnya penelitian Vai et al. (2020) Development Of Lectora Inspire Based Learning Media For Human Body Anatomy dan penelitian ini menghasilkan media pembelajaran pencak silat berbasis lectora ispire.

Tetapi yang menjadi kendala adalah ketika sekolah belum bisa menyiapkan perangkat internet dan bahkan untuk sekolah-sekolah yang jauh terpencil, sangat tidak mungkin menggunakan media berbasis digital guru bisa menggunakannya karena keterbatasan perangkat internet dan keterbatasan perangkat pendukung yang dimiliki oleh siswa berupa handphone. Hal ini selaras dengan hasil kajian literatur Puspitasari (2019) dengan judul Penerapan Media Pembelajaran Fisika Menggunakan Modul Cetak Dan Modul Elektronik Pada Siswa SMA mengungkapkan kelemahan media pembelajaran berbasis elektronik yang perlu kesiapan yang matang dalam penggunaannya dan fasilitas yang dimiliki siswa ataupun guru yang terbatas, dan umumnya media pembelajaran berbasis elektronik tidak membuat bagian untuk memuat catatan.

Peneliti disini mencoba mengembangkan sebuah media pembelajaran dengan menggunakan media gambar terutama dalam penelitiannya ini terfokus pada keterampilan permainan bola voli khusus pada keterampilan passing bawah. Musfiqon (2012) media gambar memiliki kelebihan untuk digunakan dalam proses belajar mengajar, karena media gambar memiliki sifat yang konkret sehingga lebih mampu dalam menunjukan inti permasalahan dibandingkan dengan kata verbal dan media gambar tidak terikat ruang dan waktu. Di dalam hasil penelitian (Suwiwa et al., 2017) yang mengangkat judul Pengembangan Media Pembelajaran Teknik Dasar Kuda-Kuda Dalam Pencak Silat Dengan Kartu Bergambar. Selanjutnya (Mudianti et al., 2018) dengan judul Pengaruh Penerapan Model Pembelajaran Project Based Learning Dengan Berbantuan Media Kartu Bergambar Terhadap Hasil Belajar Teknik Dasar Tendangan Pencak Silat di mana hasil penelitiannya adalah bahwa penerapan model pembelajaran project based learning dengan berbantuan media kartu bergambar berpengaruh signifikan terhadap peningkatan hasil belajar teknik dasar tendangan pencak silat. Kemudian hasil data penelitian Budi (2014) yang berjudul Penggunaan Media Audiovisual Dengan Media Gambar Terhadap Hasil Belajar Shooting Bola Basket diketahui bahwa terdapat peningkatan hasil belajar dengan menggunakan media gambar sebesar $78,25 \%$ dan terdapat peningkatan

Dari kedua penelitian tersebut memfokuskan kepada materi ajar pencak silat dimana dalam proses aplikasinya media gambar yang digunakan sangat membantu dalam proses 
peningkatan hasil belajar tendangan, selanjutnya satu penelitian lainnya mefokuskan media audiovisual dengan media gambar untuk meningkatkan hasil belajar shooting. Pada penelitian yang penulis lakukan dari hasil implementasi pada kelompok kecil, tergambar dari hasil penelitian, bahwa penggunaan media pembelajaran pasing bawah dengan menggunakan media gambar dikategorikan baik dan layak untuk digunakan pada kelompok kecil. Untuk itu pada pengembangan media selanjutnya agar produk ini bisa digunakan, maka perlu dilakukan uji coba pada kelompok besar, tetapi yang menjadi fokus dalam penelitian ini adalah kebermanfaatan media ini sebagai media belajar pada daerah yang tidak memiliki akses secara teknologi dan keterbatasan guru mengembangkan media belajar disekolah tersebut.

\section{SIMPULAN}

Kesimpulan yang dikemukakan pada hasil penelitian pengembangan bahwa media pembelajaran gambar passing bawah dalam permainan bola voli dapat diterapkan dengan baik pada sekolah yang tidak memiliki akses secara teknologi. Pengembangan media pembelajaran teknik passing bawah dengan menggunakan media gambar ini di khususkan pada SMP Santa Veronika, namun jika ingin di gunakan secara luas perlu melakukan pengujian secara kelompok besar dalam penggunaaan media ini untuk mengetahui apakah media pembelajaran ini benar-benar dapat digunakan oleh pengguna secara luas.

\section{DAFTAR PUSTAKA}

Amir, A. (2016). Penggunaan media gambar dalam pembelajaran matematika. Jurnal Eksakta, 2(1), 34-40.

Branch, R. M. (2020). Instructional Design: The ADDIE Approach. In Encyclopedia of Creativity, Invention, Innovation and Entrepreneurship. https://doi.org/10.1007/978-3-319-153476_300893

Budi, B. A. S. (2014). Penggunaan Media Audiovisual Dengan Media Gambar Terhadap Hasil Belajar Shooting Bola Basket (Studi pada Siswa Kelas VIII SMP Negeri 1 Jatiroto Kabupaten Lumajang). Jurnal Pendidikan Olahraga Dan Kesehatan, 2(3).

Cecep, K., \& Bambang, S. (2011). Media Pembelajaran Manual dan Digital. Ghalia Indonesia.

Darst, P. W., Pangrazi, R. P., Brusseau Jr, T., \& Erwin, H. (2014). Dynamic physical education for secondary school students. Pearson.

Dewi, N., Murtinugraha, R. E., \& Arthur, R. (2018). Pengembangan Media Pembelajaran Interaktif Pada Mata Kuliah Teori Dan Praktik Plambing Di Program Studi S1 Pvkb Unj. Jurnal PenSil, 7(2), 95-104. https://doi.org/10.21009/pensil.7.2.6

Fani, R. A., \& Sukoco, P. (2019). Volleyball learning media using method of teaching games for understanding adobe flash-based. Psychology, Evaluation, and Technology in Educational Research, 2(1), 34. https://doi.org/10.33292/petier.v2i1.6

Fitria, A. D. (2017). Pengembangan Media Gambar Berbasis Potensi Lokal pada Pembelajaran Materi Keanekaragaman Hayati di Kelas X SMAN 1 Pitu Riase Kab. Sidenreng Rappang. Universitas Islam Negeri Alauddin Makassar.

Hanief, Y. N. (2017). Membentuk gerak dasar pada siswa sekolah dasar melalui permainan 
tradisional. JOURNAL OF SPORTIF, 1(1), 60-73.

Haryoko, S. (2012). Efektivitas pemanfaatan media audio-visual sebagai alternatif optimalisasi model pembelajaran. Jurnal Edukasi Elektro, 5(1).

Irfiandita, R. M. (2014). Penerapan Media Poster Dan Media Audiovisual Terhadap Hasil Belajar Pada Materi Passing Bawah Bolavoli (Studi pada Siswa Kelas VIII SMP Negeri 1 Mojosari Kabupaten Mojokerto). Jurnal Pendidikan Olahraga Dan Kesehatan, 2(3).

Kesumawati, S. A., Rahayu, T., \& Rahayu, S. (2019). Game model to increase fundamental movement skills in children with mild intellectual disability. International Conference on Science and Education and Technology 2018 (ISET 2018), 431-436.

Kuswoyo, C. Y. (2013). Meningkatan hasil belajar passing bawah bola voli mini melalui permainan bola berantai pada Siswa kelas V SD Negeri Tengaran 01 kec. Tengaran kab. Semarang Tahun 2013. Universitas Negeri Semarang.

Leech, T., \& Marston, R. (2016). Promoting physical activity beyond physical education by facilitating student-designed games. Journal of Physical Education, Recreation \& Dance, 87(9), 8-13.

Mudianti, N. P. N. N., Astra, I. K. B., \& Suwiwa, I. G. (2018). Pengaruh Penerapan Model Pembelajaran Project Based Learning dengan Berbantuan Media Kartu Bergambar Terhadap Hasil Belajar Teknik Dasar Tendangan Pencak Silat. Jurnal Pendidikan Jasmani, Olahraga Dan Kesehatan Undiksha, 5(2).

Musfiqon. (2012). Pengembangan Media dan Sumber Pembelajaran. Prestasi Pustaka Raya.

Mustaqim, I. (2017). Pengembangan media pembelajaran berbasis augmented reality. Jurnal Edukasi Elektro, 1(1).

Nasution, N. S. (2018). Pengembangan Kecerdasan Sosial Melalui Metode Pembelajaran Outdoor Education Dalam Pendidikan Jasmani. JUDIKA(Jurnal Pendidikan UNSIKA), 6, 7380. http://journal.unsika.ac.id/index.php/judika

Puspitasari, A. D. (2019). Penerapan Media Pembelajaran Fisika Menggunakan Modul Cetak dan Modul Elektronik pada Siswa SMA. Jurnal Pendidikan Fisika, 7(1), 17-25.

Roberts, T., Jackson, C., Mohr-Schroeder, M. J., Bush, S. B., Maiorca, C., Cavalcanti, M., Craig Schroeder, D., Delaney, A., Putnam, L., \& Cremeans, C. (2018). Students' perceptions of STEM learning after participating in a summer informal learning experience. International Journal of STEM Education, 5(1). https://doi.org/10.1186/s40594-0180133-4

Santoso, D. A. (2019). Peran Pengembangan Media Terhadap Keberhasilan Pembelajaran PJOK di Sekolah. Prosiding Seminar Nasional IPTEK ..., 12-16. https://ejournal.unibabwi.ac.id/index.php/semnassenalog/article/view/585

Sarjianto, D. S. (2010). Pendidikan Jasmani Olahraga dan Kesehatan Kelas VIII. PT Intan 


\section{Journal of Sport Education (JOPE), 3 (2) 2021 - 136}

Aref Vai ${ }^{*}$, Jul Ferdi Jawak ${ }^{2}$, Ni Putu Nita Wijayanti ${ }^{3}$, Aulia Gusdernawati ${ }^{4}$

Pariwara.

Sugiyono. (2019). Metode Penelitian dan Pengembangan (Research and Development). Alfabeta.

Suwiwa, I. G., Astra, I. K. B., \& Astawa, I. M. Y. (2017). Pengembangan Media Pembelajaran Teknik Dasar Kuda-Kuda Dalam Pencak Silat Dengan Kartu Bergambar. Seminar Nasional Riset Inovatif, 5, 816-823.

Vai, A., Juita, A., \& Sulaastio, A. (2019). The Media Development of Pencak Silat Learning Multimedia Based at SMA/MA. 5th International Conference on Physical Education, Sport, and Health (ACPES 19), 178-182.

Vai, A., Nanda, F. A., Saputro, D. P., \& Rahmatullah, M. I. (2021). Lectora inspire software development in the learning of pencak silat. Journal Sport Area, 6(1), 109-118.

Vai, A., Slamet, S., Aspa, A. P., Rahmatullah, M. I., \& Nanda, F. A. (2020). Development Of Lectora Inspire Based Learning Media For Human Body Anatomy. Jurnal MensSana, 5(2), 171-178.

Valentino, R., \& Ihsan, N. (2018). Pengembangan Media Pembelajaran Pencak Silat Berbasis Macromedia Flash 8 Untuk Sekolah Menengah Pertama. Jurnal JPDO, 1(1), 83-87. 